\title{
Primary Layout Of The Earliest Shophouses In The Small Towns (1880s - 1930s) - A Case Study In Perak
}

\author{
Mohd Jaki Bin Mamat \\ Universiti Sains Malaysia \\ mohdjaki@usm.my
}

Article History: Received:11 January 2021; Accepted: 27 February 2021; Published online: 5 April 2021

\begin{abstract}
The layout of the shophouse combined two main functions, as a residence and commercial building. The living and business activities were main influences on how these spaces were designed in the shophouse that first made its appearance in the small towns and surrounding areas in the early $19^{\text {th }}$ and $20^{\text {th }}$ centuries. In Malaysia, in particular Perak, these shophouses are still intact and have enabled the opportunity to identify and record the layout features of interior space for this study. From interviews and measured drawing of the early shophouses in 16 small towns in Perak, a complete set of layout plans were produced and analysed. This study has found that the domestic (or family) space was given prominence in terms of size; thus, the lifestyle was a determining factor in the building's layout for interior space. Yet, the importance of business sets its relevant space at the forefront where customers are received.
\end{abstract}

$\underline{\text { Keywords; layout, shophouses, business area, domestic space, open area }}$

\section{Introduction}

The shophouse is a building that is typically found in south China and south-east Asia (Shi, 2016) that is effectively functional in a town where there is a combination of commerce and residence within the same zone (Rina, 2015). The study shows such a combination is still relevant in some countries like Taiwan (Chen, 2011), Hong Kong (Wadu, 2018), India (Anjali, 2017), Indonesia (Rina, 2015), including Malaysia (Wang, 2015). In Malaysia, since its appearance to present-day, the shophouse has played an essential role in the urban socioeconomic development. Over time, commerce has flourished into services as well, and today many towns in the country have blocks of historical shophouses that have transformed into local heritage centres, like Malacca and Penang (Tan, 2019; Shahrul, 2016; Omar, 2011), which generate income through tourism.

The shophouse reflects the interaction between economic activity and architecture, especially in the use of space (Wang, 2015). The mixed design catering to the way of life and culture with commercial function needs to be further appreciated. The words' shop' and 'house' in Malaysia are self-explanatory to its function, that is, business and residence. It conveys the aim of the study, which is to highlight the layout of the early shophouse found in 16 small towns in Perak. This vital evaluation is to understand the space features of the early buildings in each town.

Perak was the first state to receive British administration in Malaysia, whilst being one of the biggest tin producers in the world towards the end of the $19^{\text {th }}$ century, and thus witnessed a large immigrant population from China. The latter's entry changed the physical shape of towns with shophouses and business premises being built (Mohd Jaki, 2018; Ming, 2009; Khoo Salma, 2005). This study has significant implications as it gives added value to detailed information concerning the use of internal space in the Malaysian shophouse, which may be necessary to future related studies.

\section{Literature review}

\subsection{Shophouse}

The design of the shophouse was said to have originated in the Song Dynasty (C.E. 960-1279) when there was rapid economic development whereby the construction of houses was increasingly needed in commercial areas, and tandem with larger business spaces for the residences. In the early shophouse, the residence was at the back and then moved to the upper floor; this was the ideal arrangement for such in China then (Wang, 2015). It was also believed to have originated from the arcade system first discovered in European towns during the Middle Ages (Shi, 2016). Since then the shophouse has evolved to what it is today. It differed from Europe during the industrial revolution of $19^{\text {th }}-20^{\text {th }}$ centuries when the same building which housed the business and residence 
became less practical and then led to a new trend whereby the living quarters were separated from the trade premises. Subsequently, such led to the building of residences in the centre of commercial areas which later became urban housing (Sneed, 2011; Hoskins, 2018 ).

Nevertheless, the shophouse remains popular in Asia, mostly south-east Asia. In Malaysia, it sprouted steadily between the $19^{\text {th }}$ till the early $20^{\text {th }}$ centuries in tandem with increasing immigrants from south China. Most of these buildings were a combo of business and residential premises, an optimal formula in catering to both activities under one roof and were found in big and small towns in Malaya then (Omar, 2011).

In the nascent towns in Perak, most of the shophouses were built on lots set by the British and also individual landowners who were local Malays (Mohd Jaki, 2018; Wan Hashimah, 2015). These formed the early townships in Malaysia, influenced by the presence of the Chinese, Europeans and locals (William, 2014; Mohd Jaki, 2020). Undoubtedly, the shophouse was a diverse ecosystem of settlement and commerce in a town or city (Anjali, 2017; Jones,2019), an early urban formation, although now such premises are entirely commercial, especially in Singapore, as well as the norm today in the towns and cities of Malaysia (William, 2014). The shophouse is now the image of an old town in Malaysia, part of an unchanged landscape. In fact, some have become the main pulse due to its central location in towns and cities (Wan Hashimah, 2015). Whatever the business, it is a part of the urban community and a visitors' haunt today (Khare, 2014). Its five-footway that runs along each row is part of an essential network for pedestrians in town and enables the shops to adapt to daily community living while carrying out their businesses (Wan Hashimah, 2015).

\subsection{Interior layout of the shophouse}

In the Malaysian context, the architecture of the shophouse draws its influence from the Chinese community (Tan, 2014) whose immigrants mostly came from South China. The layout reflects the daily life then which was closely linked to culture and religion but adapted to local factors like the hot Malaysian climate and availability of construction materials (Wang, 2015). Although there were shophouses built by the Malays, they were not regarded as residences because the community had their own homes elsewhere around the towns.

In Malaysia, the shophouse was divided into two spaces: the ground floor for business, the upper floor for residence. There were also some private spaces downstairs, though based on the location and size, the business area was the most important given that it was in the forefront (Tan, 2014). In some Asian countries with big commercial buildings, it was noted that while the ground floor was for business, the upper floor was the living quarters for the lower and middle classes. Though it differed in ownership as to the level of the building, it still separated the commercial and living spaces. Similarly, in Europe, commercial buildings like the arcade saw the upper floor area becoming a residential space when the trading space became more critical especially in the town centre. The ground floor was increasingly busy with traffic at shop fronts which were later widened to increase accesses to vehicles and pedestrians (Plevoets, 2011). In India, some commercial units alternated with residential ones along the same row (Wadu, 2018). At others, the shophouse had the living area at the back while its business space was in front (Anjali, 2017).

During the boom of shophouse construction in Malaysia from mid- $19^{\text {th }}$ to early $20^{\text {th }}$ centuries, it was noted that the interior layout was based on the business activity similar to that of trade-and-residence found in south China. However, the local facade reflected a blend of European and Malay architectural features while adhering to the British standards then (Mohd Jaki, 2020; William, 2014). Thus, the planning of space was greatly influenced by the business activity whereby the shopper was given priority, and so determined the size and placement of the retail space (Kim, 2012). This is because, in business theory, the said space must be creative, for example, a brand connection to the shop, display, as well as space identity. The layout caters to the customer and is determined by the experience felt by them (Kent, 2007). The ambience inside is more important than the merchandise as it helps draw the attention of the customer (Kim, 2012).

Cleber's (2018) study of business social contact can be equated to the role of the shophouse because a strong social bond can be established between the seller and buyer inside the premises as the former is always present during the sale activity. This reinforces the features of the shophouse in its early days as a place of business and dwelling. The combined function of business and residence fulfils the mixed-use principle in a layout (Wang, 2015). Whereas, air circulation is determined by the size and shape of the building, and in the shophouse where it is long and narrow, also influences the design of interior space which is linear-like (Raed, 2011). The units were built in a row with party walls separating each other (Wang, 2015). Generally, the shophouse comprised of 3 sections the front called the first hall, central space, and the back termed the second hall (Song, 2011). 
The front consisted of two spaces: the interior, which is the business area, and the five-footway outside to welcome visitors (Wang, 2015; Song, 2014; Song 2011; Chen, 2011). The walkway was a link to the inside and thus considered the initial step before entering the shophouse. It was also a place of shade (Laina, 2018) and protected customers from dust and dirt from the roads outside (Plevoets, 2011; Tung, 2018). These walkways were linked and formed a network for pedestrians to other shops, not just on the same row but beyond to other parts of town (Wahyuni, 2015; William, 2014). Therefore, the shophouse at its start was a concept of urban commerce and its relevance is perpetuated to present-day where it now has clear features, pedestrian accessability, an allocated space for buying and selling, as well as security where the retailer is present throughout the business transaction (Gunes, 2015). Such a space also endows the area of having sense-of-place marketing (Wadu, 2018).

After the five-footway, the front of the interior is a business space, its position and large area, making it the vital location (Wang, 2015; Song, 2014). According to Plevoets (2011), the open front space became popular at the end of the $18^{\text {th }}$ century when the mode of the trade from oral salesmanship changed to the visual promotion, and people often strolled past there. This was the most prominent area for interaction between customer and trader as well as for displayed merchandise (Anjali, 2017). Zhang (2017) noted that the distinguishing and display of various goods were important in the retail business. In his study about space-sharing, though not refering to the shophouse, states that the pertinent space fulfills the principle of cost-saving in business as well as complementary and versatility of the place. This arrangement meets the criteria of commercial space in a shophouse.

After the front hall, the central space has a courtyard to differentiate the business and the owner's private spaces, respectively (Anjali, 2017). This feature is usually an open space to ensure that each unit has air movement (Wang, 2015; Song, 2014). This was important considering each shophouse had great depth, some reaching a 100-foot long, with party walls between units in a row, resulting in air being trapped if there were no open courtyard or air well (Tetsu, 2017; Anjali, 2017; Mohd Azuan, 2015). This layout was influenced by the hot weather in Malaysia (Tetsu, 2017, Omar, 2011), and study data have shown that a courtyard could reduce the heat by $5-6^{\circ} \mathrm{C}$ compared to the outside of the building (Laina, 2018). According to Wang (2015), the courtyard was a Dutch and Portuguese feature for 2-storey shophouses.

Some shophouses also had a semi-opening in their central area which housed other spaces (Wang, 2015; Song, 2014), for example, the dining area and storage place. At this mid-section is also found the staircase leading to the upper floor (Laina, 2018; Mohd Azuan, 2015; Song, 2011). Occasionally, there were some units which were shorter without the courtyard; instead, such types had an open space at the back of the building (Wang, 2015). The back portion with a roof overhead housed the dining area, kitchen, bathroom and toilet in individual rooms for their pertinent functions (Wang, 2015; Laina, 2018; Mohd Azuan, 2015). The rear-most section was left unroofed as this was where laundry and simple gardening activities were carried out. A door opens to a lane at the back of the shophouse (Song, 2014). These physical features of the backyard contributed to the urban verdure which was included in the planning since the early forming of a town (Wahyuni, 2015).

For the two-storey shophouse, the upper floor was for bedrooms, thus, making this the most private area (Anjali, 2017). The rooms consisted of the main bedroom at the front and a corridor that led to other rooms in the middle (Wang, 2015; Mohd Azuan, 2015). Concerning mixed-use, the bedrooms (Song, 2014) found at the upper floor meets the dual-function of the shophouse, in that, as a residence and business place. This concept is still relevant if adopted today (Chen, 2011). Some shophouses have incorporated the maximum number of rooms until the back. For such, the mid-section is usually turned into a hall or a multipurpose area, thereby making it a family space. The shophouse then does not have an open courtyard below because a floor has been constructed above to cater to this. The open space is replaced by a backyard (Wang, 2015; Mohd Azuan, 2015).

Generally, the shophouse layout was designed to fulfil customers' needs and attract their patronage while having a defined function in a commercial space. It provided a facility for the transaction, and at the same time met the trader's needs to carry out his business and the ability to maintain his daily life. These two aspects gradually contributed to the optimal interior space design and were widely favoured by the traders for the premises in the big and small towns of Malaysia (Wan Hashimah, 2015; Sneed, 2011). Even though there were some variations in the interior space in terms of size, scale and amenities, these mainly arose from factors of local cost, technology, knowledge and skills of the place and state (Wang, 2015).

Thus, this study fulfils the objective of appreciating the primary layout of the shophouse interior space for all towns in Perak and thereby justifies the design features of combining space as a business and residence entity. Data from the 16 towns studied here makes a critical reference for future studies related to space usage. 


\section{Methodology}

This study is entirely based on measured drawings to understand further the layout and interior space usage of the shophouse. Interviews were carried out only for the identification of the first or earliest shophouse in the pertinent town. Given that most of the buildings were from 1880 to 1931, it was relatively easy to trace the local folks that knew these early buildings which still bore defined features for remeasurement. Interview respondents were selected from local authorities such as the village head, penghulu, and the district office. These parties had direct involvement with the local administration and possessed recorded and unrecorded information about the earliest shophouses in the respective areas.

Subsequently, interviews were carried out amongst the owners and users (tenants) of the shophouse to dwell more in-depth into the early layout and its function. The data collected is believed to be accurate, taking into consideration that the respondent had inherited the property from the original owner. The majority of these repondents still retained good memories as they were born and raised in these shophouses, especially those in Malim Nawar, Tanjung Rambutan, Kuala Sepetang, Kuala Kurau, Pusing, Bagan Datuk, Parit, Klian Intan, Sungkai, Manong, Pengkalan Hulu, Lenggong and Papan. For others who had acquired the buildings, information was derived from the original owners, like that at Lumut. For respondents who are now users of the shophouse as tenants, information was obtained from the descendants of the original owner such as that at Padang Rengas and Chenderiang. Data integrity from this group was also vital as it provided enlightenment to the original space before it was (currently) used or renovated to meet present-day business needs. The measured drawings of the shophouse were produced based on the original architecture and layout, and not after renovations.

Apart from this, the data was also collected were from the first shophouse in each town. As such, there was no local layout influence that was used as a reference apart from factors of weather, building materials and architectural facade which were subject to the local environment. The study produced complete measured drawings using AutoCadd software which gave focus to layout features on space usage.

\section{Analysis}

The layout was analysed based on three main functions: business (public), domestic (family) and open area. The business space included that for trade and providing service to the customer. Most of the shophouses in this study comprise of premises for the retail business except for that in Pengkalan Hulu which functioned as a restaurant. The domestic space consists of an area to come together, the kitchen, dining area, bedroom, as well as bathroom and toilet. This was regarded as a private space. The open space served as a multi-purpose area such as that for washing and drying of clothes, and simple gardening activity. This area was essential to mitigate the humid weather and provide ventilation inside the shophouse. Some of these were regarded as boundaries between the public and private spaces.

Measurements were taken to appreciate the features of interior space and the function of each. The comparison was subsequently made between the three spaces mentioned above to identify the emphasis on particular spaces. This emphasis was assessed by way of allocated space, the biggest being the most important and vice-versa. In the calculation of overall space, the walkway was not included in any of the categories as it was considered a passage only and not a mandatory need.

There have been some changes to current needs; for example, the bedroom on the upper floor, though still existing in some, was no longer used. These places though difficult to be drawn were identified as the family area and hall and was originally part of the bedroom. All these data were obtained upon soliciting the confirmation of the owner and users of the shophouses under study. The measurements conducted on 16 shophouses in the 16 towns have successfully produced a set of measured drawings, as a result of this outlined in Diagram 1.

Diagram 1 - 16: Measured drawings of the earliest shophouse found in 16 small towns in Perak. 
Diagram 1: Papan Town, 1880s

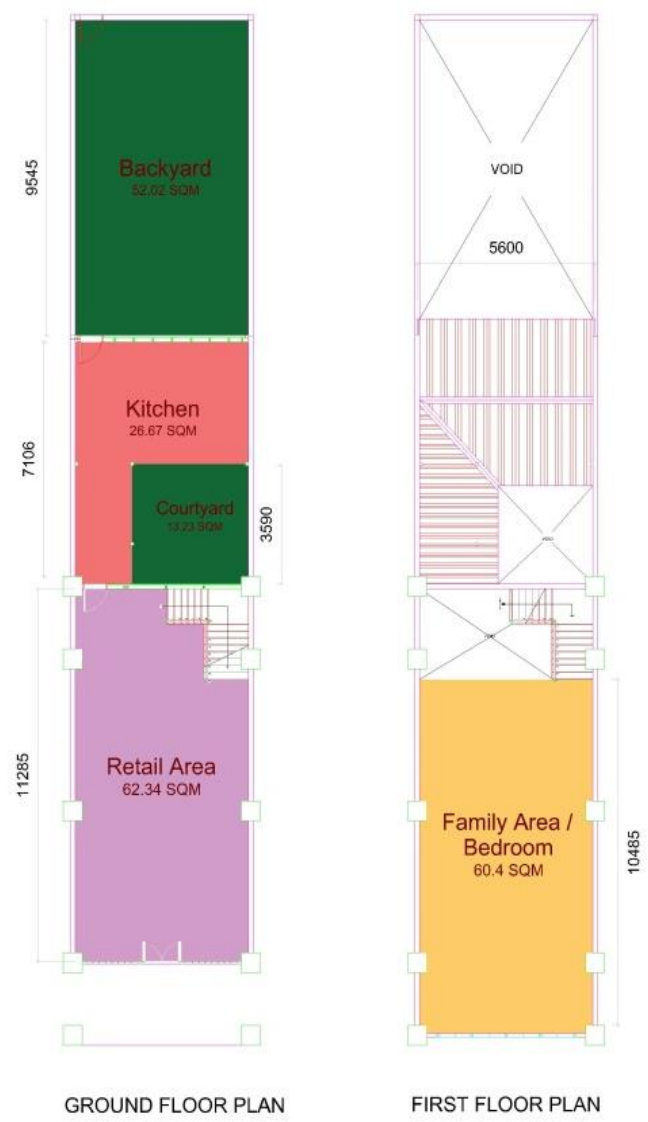

Diagram 3: Pusing Town, 1890s

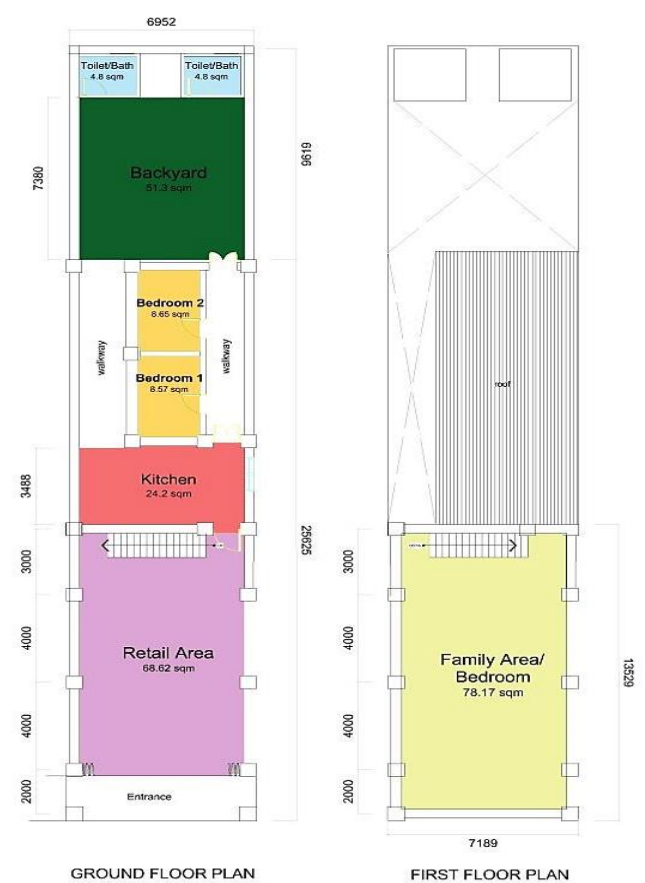

Diagram 2: Kuala Sepetang (Port Weld), 1890 6020

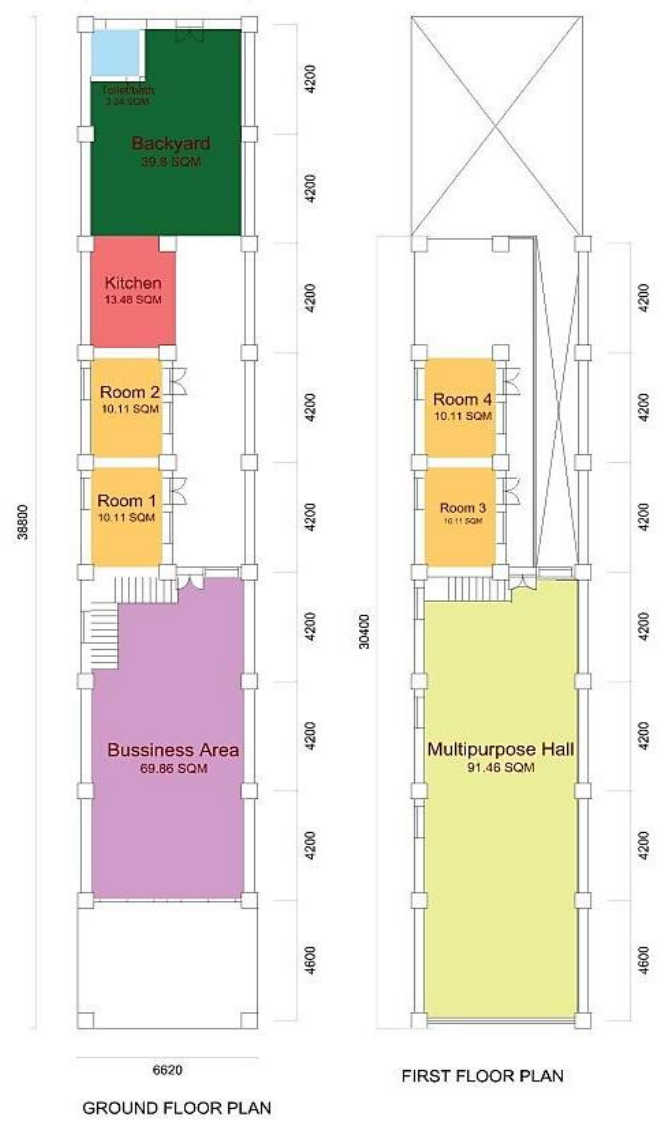

Diagram 4: Sungkai Town, 1900

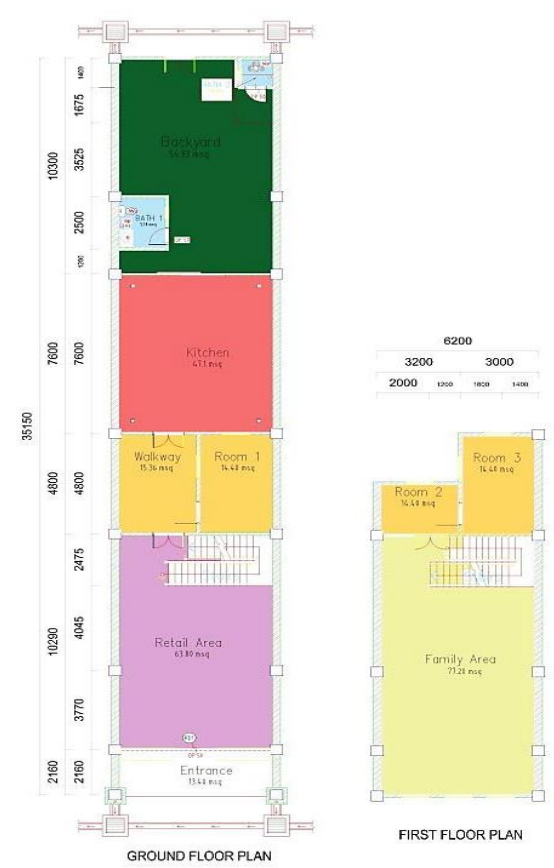


Primary Layout Of The Earliest Shophouses In The Small Towns (1880s - 1930s) - A Case Study In Perak

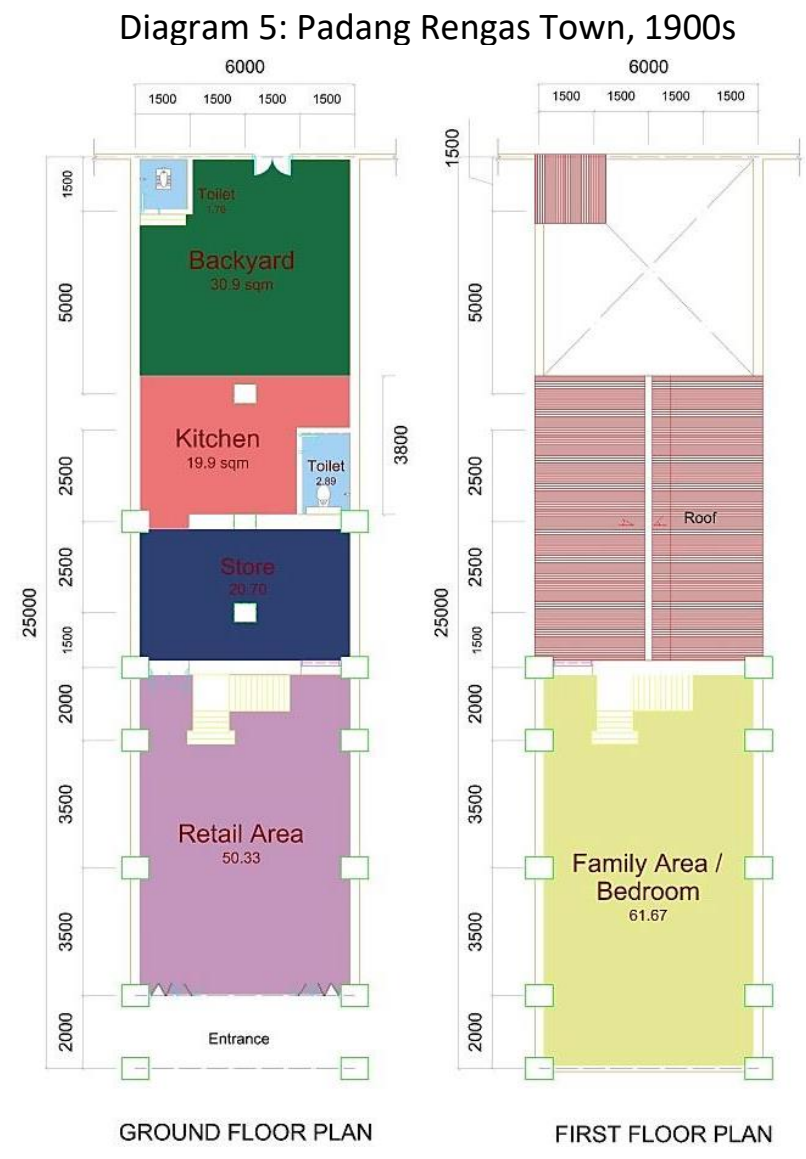

Diagram 7: Klian Intan Town, 1909

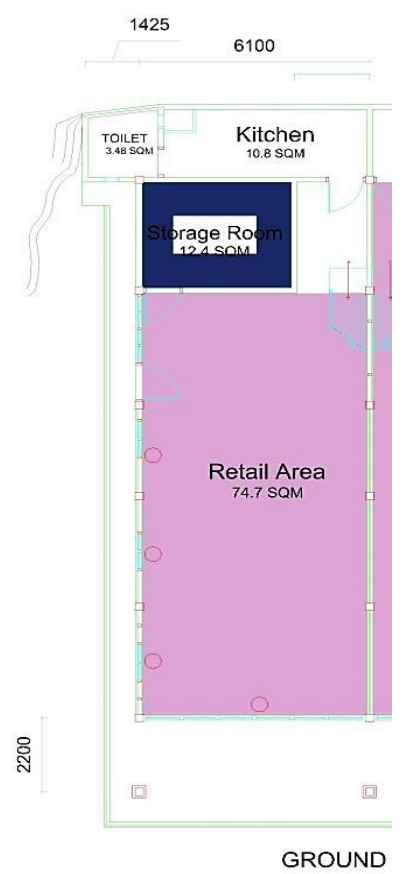

Diagram 6: Kuala Kurau Town, 1900s

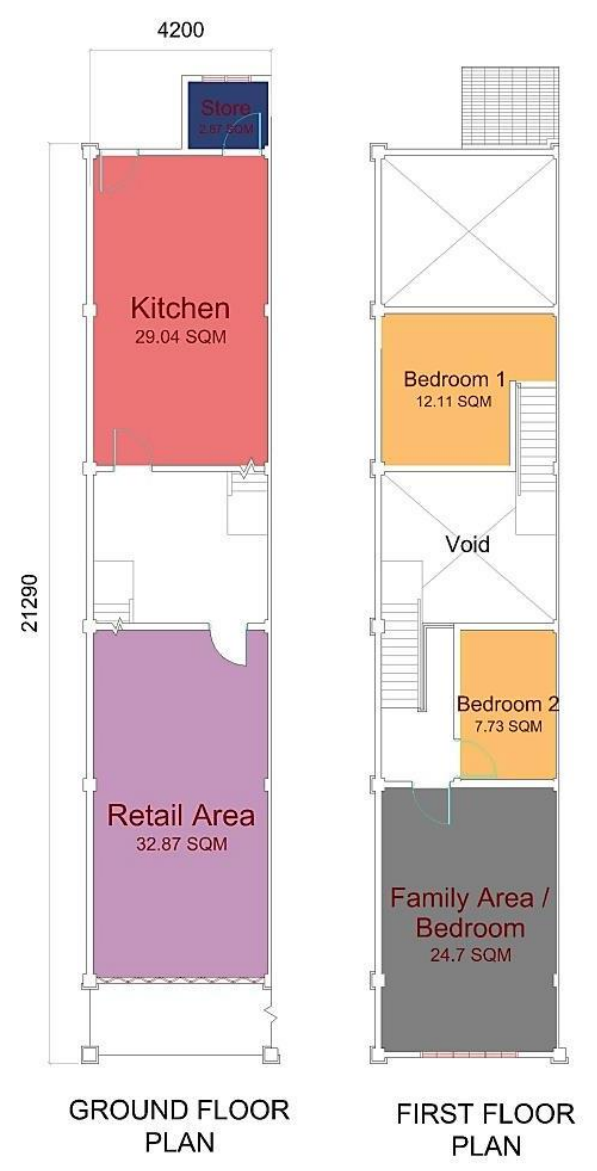

Diagram 8: Lenggong Town, 1915

7150

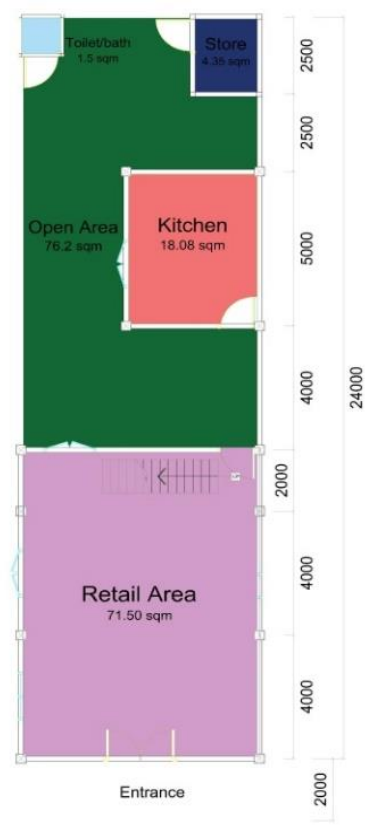

GROUND FLOOR PLAN

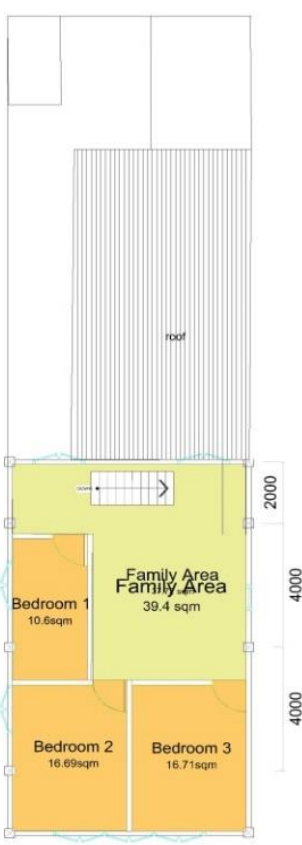

FIRST FLOOR PLAN 
Diagram 9: Tanjung Rambutan Town, 1922 6630

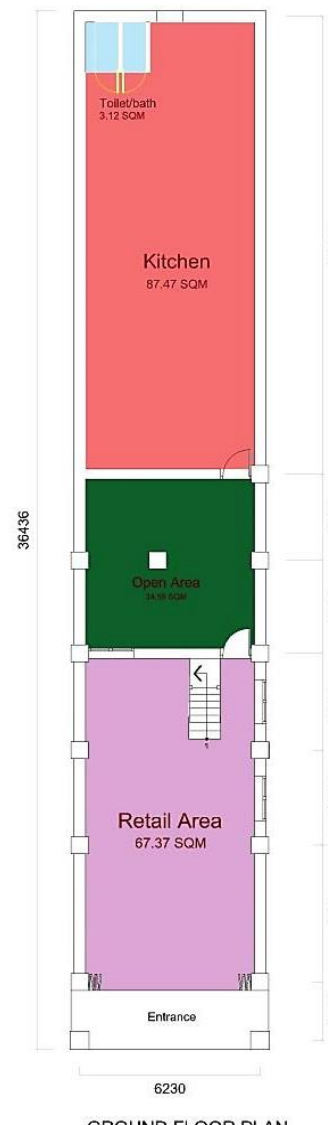

GROUND FLOOR PLAN

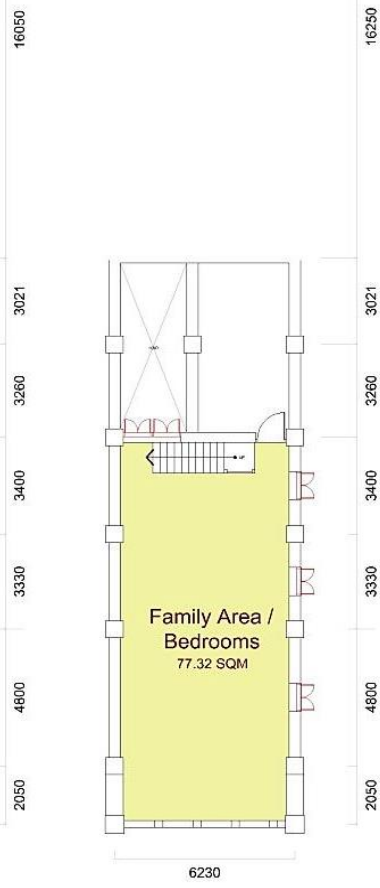

FIRST FLOOR PLAN
兽

ธ్

昍

哭

兽

帝

용

Diagram 11: Chenderiang Town, 1920s

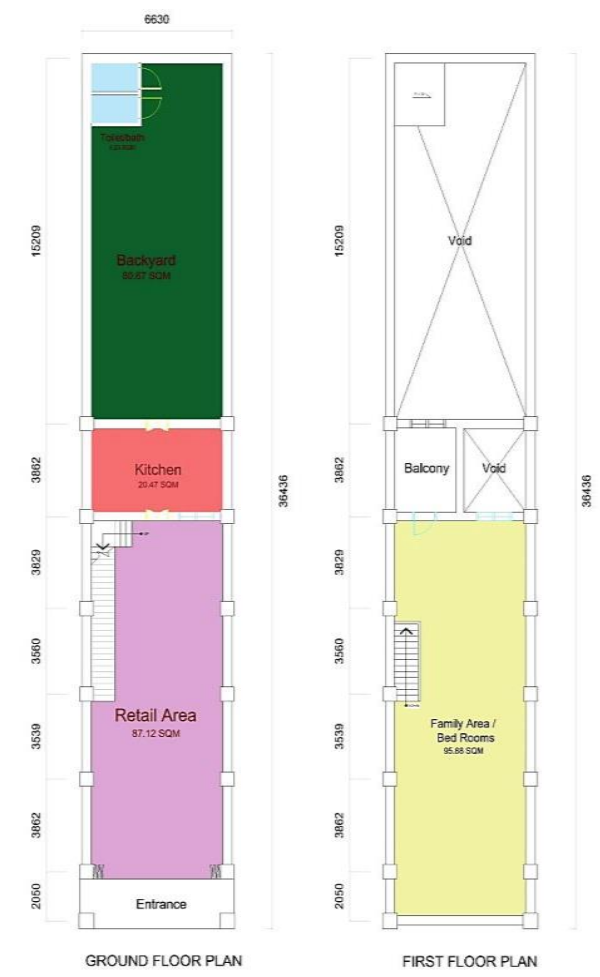

Diagram 10: Lumut Town, 1920s
7915

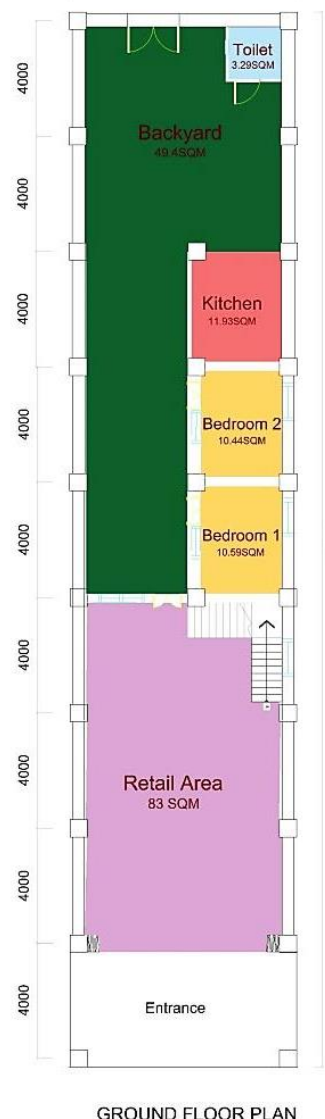

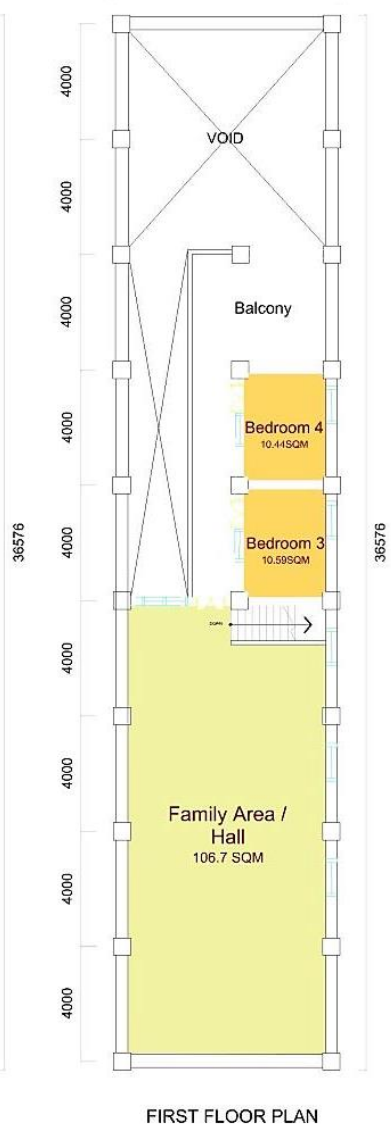

Diagram 12: Manong Town, 1920s

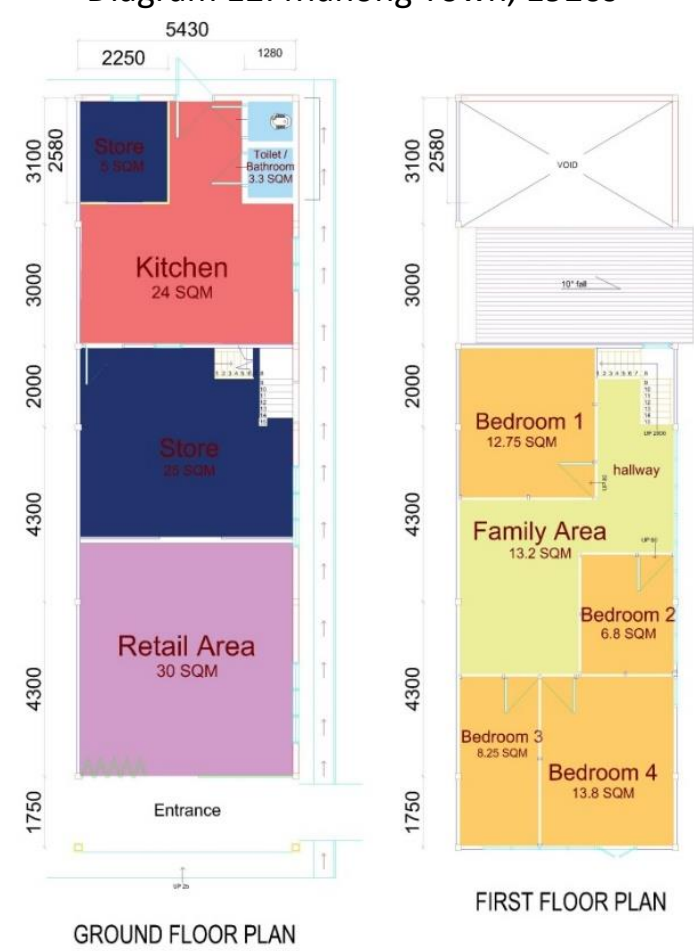


Diagram 13: Malim Nawar Town, 1920s

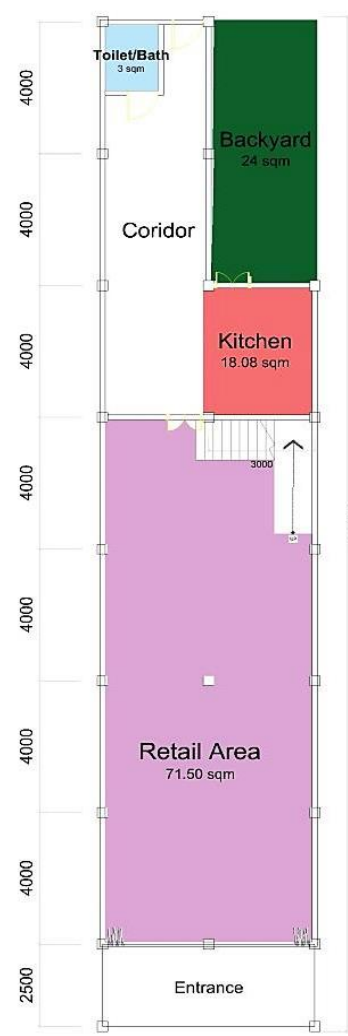

GROUND FLOOR PLAN

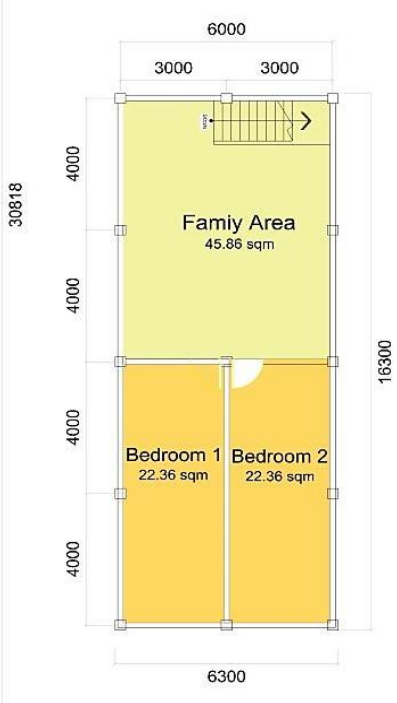

FIRST FLOOR PLAN

Diagram 15: Parit Town, 1928
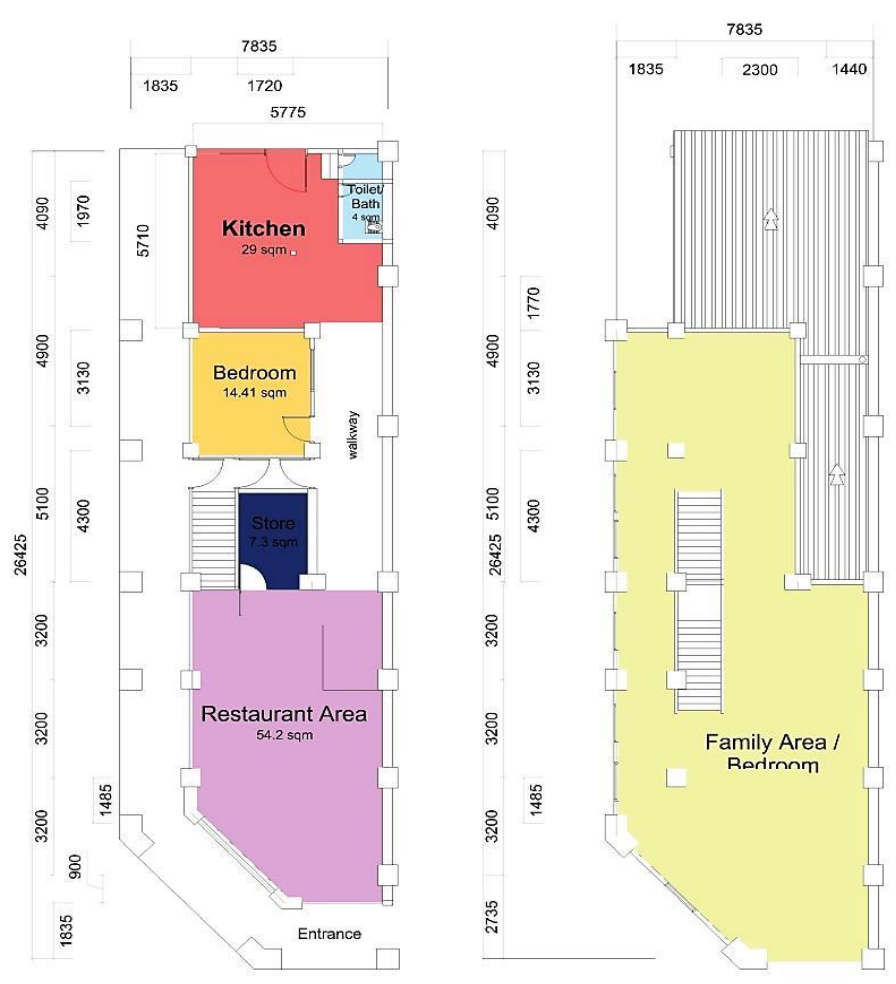

GROUND FLOOR PLAN

FIRST FLOOR PLAN

Diagram 14: Pengkalan Hulu Town, 1920s

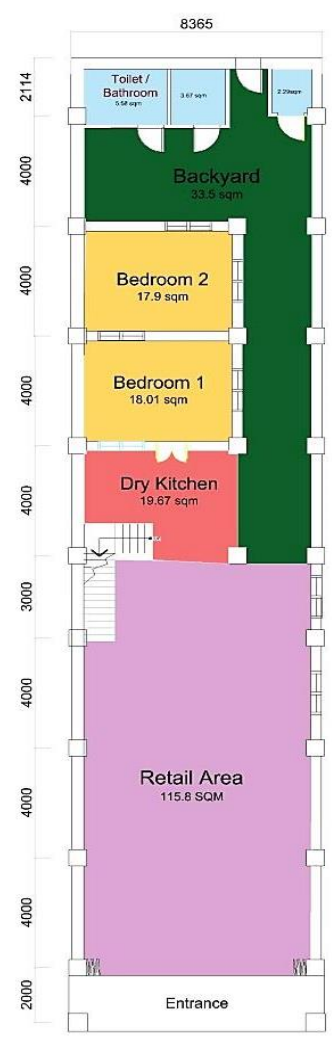

GROUND FLOOR PLAN

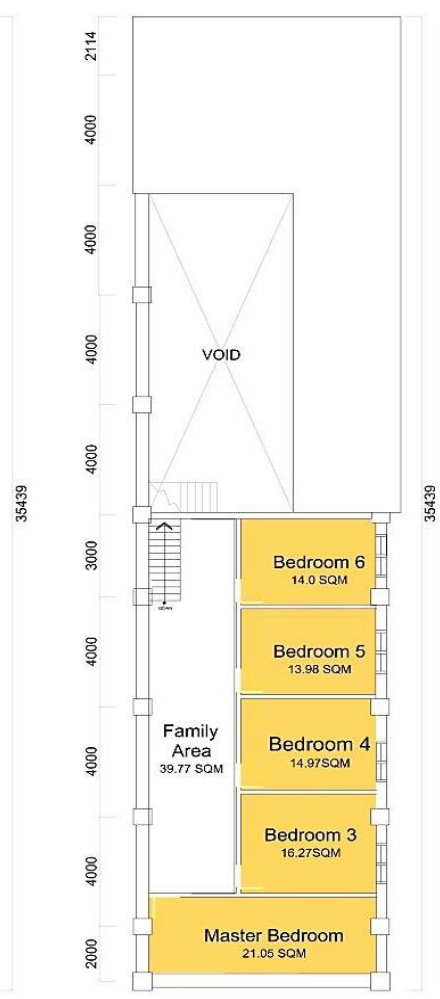

FIRST FLOOR PLAN
Diagram 16: Bagan Datuk Town, 1931

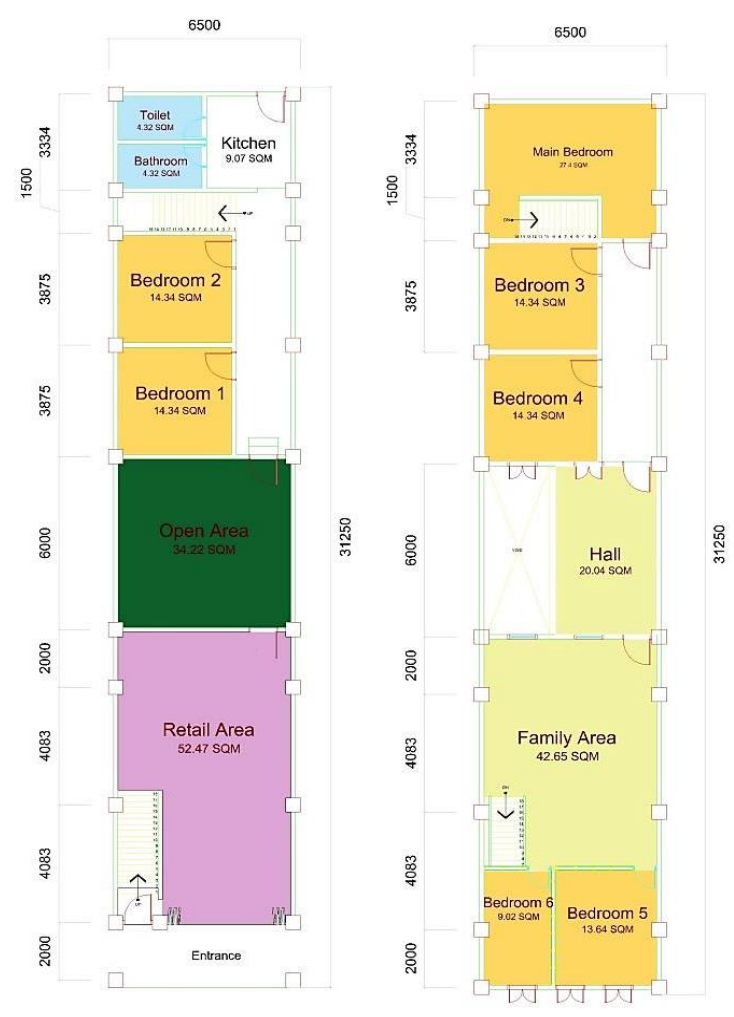

GROUND FLOOR PLAN 
Based on the layout plan of the measured drawings it was found that all of the earliest shophouses in the 16 small towns were two-storey, with the business space located on the ground floor and the family space on both the ground and upper floors. As described in the literature review, the standard layout features of the shophouse in this study were similar to those found in other states in Malaysia. The business space was at the front as one stepped in from the five-footway. Further on was the central space, which was either a courtyard or an open space with a roof overhead. This area was distinguished as a domestic space for dining, kitchen and bedroom for some shophouses. Further behind was found the backyard or a roofed-over open space where cooking and washing were done, as well as the toilet and bathroom. An open backyard was used to dry clothes and carry out simple gardening. Generally, the measured layout plan can be better appreciated, as shown in Table 1 of 'Findings'.

\section{Findings}

Table 1: Division of the three main spaces in a shophouse according to size

\begin{tabular}{|c|c|c|c|c|c|c|c|}
\hline \multirow[b]{2}{*}{ No. } & \multirow{2}{*}{$\begin{array}{c}\text { Town (Total } \\
\text { floor area in } \\
\text { sqm) }\end{array}$} & \multicolumn{6}{|c|}{ Spaces } \\
\hline & & $\begin{array}{c}\text { Business Area } \\
\text { (Floor Size in sqm) }\end{array}$ & $(\%)$ & $\begin{array}{c}\text { Domestic space } \\
\text { (Floor Size in sqm) }\end{array}$ & $(\%)$ & $\begin{array}{l}\text { Open Area (Floor } \\
\text { Size in sqm) }\end{array}$ & $(\%)$ \\
\hline 1 & $\begin{array}{l}\text { Klian Intan } \\
(220.4)\end{array}$ & 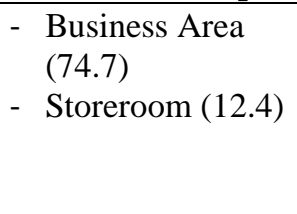 & 39.5 & $\begin{array}{l}\text { - Kitchen (10.8) } \\
\text { - Family Area / } \\
\text { Multipurpose } \\
\text { (119) } \\
\text { - Toilet/Bath (3.48) }\end{array}$ & 60.5 & None & 0 \\
\hline 2 & $\begin{array}{l}\text { Manong } \\
(142.1)\end{array}$ & 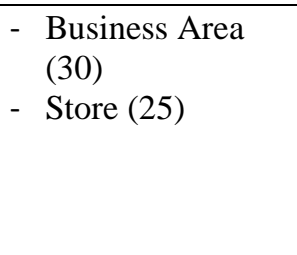 & 38.7 & $\begin{aligned} & \text { - } \text { Kitchen (24) } \\
& \text { - Family Area } \\
& \\
& \text { (13.2) } \\
& \text { - Bedroom (41.6) } \\
& \text { - Toilet/Bath (3.3) } \\
& \text { - Store (5) }\end{aligned}$ & 61.3 & - None & 0 \\
\hline 3 & $\begin{array}{l}\text { Padang } \\
\text { Rengas } \\
(187.7)\end{array}$ & 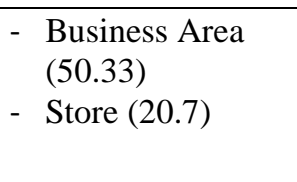 & 37.8 & $\begin{array}{l}\text { - } \text { Kitchen (19.9) } \\
\text { - Family Area / } \\
\text { Bedroom (61.67) } \\
\text { - } \text { Toilet/Bath (4.7) }\end{array}$ & 46 & - Backyard (30.9) & 16.5 \\
\hline 4 & $\begin{array}{l}\text { Malim Nawar } \\
(207.1)\end{array}$ & $\begin{array}{l}\text { - Business Area } \\
(71.5)\end{array}$ & 34.5 & $\begin{array}{l}\text { - Kitchen (18.08) } \\
\text { - Family Area } \\
\text { (45.86) } \\
\text { - Bedroom (44.7) } \\
\text { - Toilet/Bath (3) }\end{array}$ & 53.9 & - Backyard (24) & 11.6 \\
\hline 5 & $\begin{array}{l}\text { Pengkalan } \\
\text { Hulu (336.4) }\end{array}$ & $\begin{array}{l}\text { - Business Area } \\
(115.8)\end{array}$ & 34.4 & $\begin{aligned} \text { - } & \text { Kitchen (19.67) } \\
\text { - } & \text { Family Area } \\
& (39.77) \\
\text { - } & \text { Bedroom (116.2) } \\
\text { - } & \text { Toilet/Bath (11.5) }\end{aligned}$ & 55.6 & - Backyard (33.5) & 10 \\
\hline 6 & $\begin{array}{l}\text { Kuala } \\
\text { Sepetang } \\
(219)\end{array}$ & $\begin{array}{l}\text { - Business Area } \\
\text { (71.6) }\end{array}$ & 32.4 & $\begin{aligned} \text { - } & \text { Kitchen (23.1) } \\
\text { - } & \text { Hall \& Bedroom } \\
& (60.4) \\
\text { - } & \text { Toilet/Bath }(2.8)\end{aligned}$ & 39.4 & $\begin{array}{l}\text { - Backyard (53.75) } \\
\text { - Open Area (7.39) }\end{array}$ & 27.9 \\
\hline 7 & $\begin{array}{l}\text { Chenderiang } \\
(289.4)\end{array}$ & $\begin{array}{l}\text { - Business Area } \\
(87.12)\end{array}$ & 30.1 & $\begin{array}{ll}\text { - } & \text { Kitchen (20.47) } \\
\text { - } & \text { Family Area / } \\
& \text { Bedroom (95.88) } \\
\text { - } & \text { Toilet/Bath (5.23) }\end{array}$ & 42 & - Backyard (80.67) & 27.9 \\
\hline
\end{tabular}


Primary Layout Of The Earliest Shophouses In The Small Towns (1880s - 1930s) - A Case Study In Perak

\begin{tabular}{|c|c|c|c|c|c|c|c|}
\hline 8 & $\begin{array}{l}\text { Kuala Kurau } \\
\text { (124) }\end{array}$ & $\begin{array}{ll}\text { - } & \text { Business Area } \\
& (32.87) \\
- & \text { Store }(2.87)\end{array}$ & 28.8 & $\begin{array}{l}\text { - Kitchen (29.04) } \\
\text { - Family Area / } \\
\text { Bedroom (44.5 } \\
\text { - Toilet/Bath (in } \\
\text { the kitchen area) }\end{array}$ & 59.3 & - Open Area (14.7) & 11.9 \\
\hline 9 & $\begin{array}{l}\text { Lenggong } \\
(255)\end{array}$ & 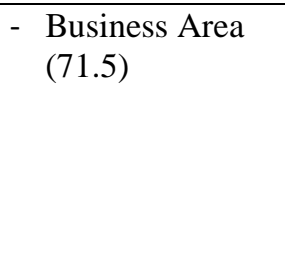 & 28 & $\begin{array}{l}\text { - Kitchen (18.08) } \\
\text { - Family Area } \\
\text { (39.4) } \\
\text { - Bedroom (44) } \\
\text { - Toilet/Bath (1.5) } \\
\text { - Store (4.35) }\end{array}$ & 42.1 & - Open Area (29.9) & \\
\hline 10 & Lumut (296.4) & $\begin{array}{l}\text { - Business Area } \\
\text { (83) }\end{array}$ & 28 & $\begin{array}{l}\text { - } \text { Kitchen (11.93) } \\
\text { - Family Area / } \\
\text { Hall (106.7) } \\
\text { - Bedroom (42.1) } \\
\text { - Toilet/Bath (3.29) }\end{array}$ & 55.3 & - Backyard (49.4) & 16.7 \\
\hline 11 & $\begin{array}{l}\text { Pusing } \\
(250.1)\end{array}$ & 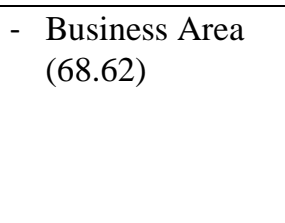 & 27.4 & $\begin{array}{l}\text { - } \text { Kitchen (24.2) } \\
\text { - Family Area } \\
\quad(78.17) \\
\text { - Bedroom (18.2) } \\
\text { - Toilet/Bath (9.6) }\end{array}$ & 52 & - Backyard (51.3) & 20.5 \\
\hline 12 & Papan (257.9) & $\begin{array}{l}\text { - Business Area } \\
(69.86)\end{array}$ & 27.1 & $\begin{array}{ll}\text { - } & \text { Kitchen (13.48) } \\
\text { - } & \text { Family Area / } \\
& \text { Bedroom (40.04) } \\
\text { - } & \text { Multipurpose } \\
& \text { Hall (91.46) } \\
\text { - } & \text { Toilet/Bath (3.24) }\end{array}$ & 57.5 & - Backyard (39.8) & 15.4 \\
\hline 13 & Parit (231.8) & 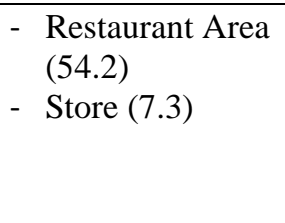 & 26.5 & $\begin{aligned} & \text { - } \text { Kitchen (29) } \\
& \text { - Family Area } \\
&(122.9) \\
& \text { - } \text { Bedroom (14.41) } \\
& \text { - } \text { Toilet/Bath (4) }\end{aligned}$ & 73.5 & - None & 0 \\
\hline 14 & $\begin{array}{l}\text { Tanjung } \\
\text { Rambutan } \\
(269.9)\end{array}$ & 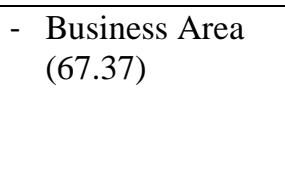 & 25 & $\begin{array}{ll}\text { - } & \text { Kitchen (87.47) } \\
\text { - } & \text { Family Area / } \\
& \text { Bedroom (77.32) } \\
\text { - } & \text { Toilet/Bath (3.12) }\end{array}$ & 62.2 & $\begin{array}{l}\text { - Open Area } \\
(34.58)\end{array}$ & 12.8 \\
\hline 15 & $\begin{array}{l}\text { Sungkai } \\
(295.2)\end{array}$ & 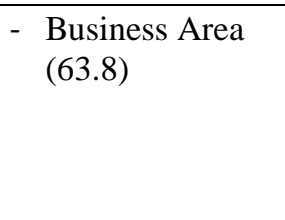 & 21.6 & $\begin{array}{l}\text { - } \text { Kitchen (47.1) } \\
\text { - Family Area } \\
\text { (77.2) } \\
\text { - Bedroom (43.2) } \\
\text { - Toilet/Bath (7) }\end{array}$ & 59.1 & - Backyard (56.92) & 19.3 \\
\hline 16 & $\begin{array}{l}\text { Bagan Datuk } \\
(274.45)\end{array}$ & 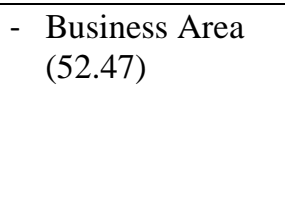 & 19.1 & $\begin{aligned} \text { - } & \text { Kitchen }(9.07) \\
\text { - } & \text { Bedroom (107.4) } \\
\text { - Family Area \& } & \text { Hall (62.7) } \\
& \text { - Toilet/Bath (8.6) }\end{aligned}$ & 68.4 & $\begin{array}{l}\text { - Open Area } \\
(34.22)\end{array}$ & 12.5 \\
\hline
\end{tabular}


For space function, only five towns allocated more than one-third (or 33.3\%) of its total area for business, whereas 11 units in the other towns provided less than 33.3\% for this. The ones in Sungkai and Bagan Datuk had the smallest spaces at $21.6 \%$ and $19.1 \%$ respectively. Although the importance of space is determined by its position at the front is the most suitable whereby all business were conducted with customers, size-wise considered, the majority of the shophouses studied here gave priority to the domestic space for family use.

It was found that all the shophouses in the 16 towns, allocated the domestic space at more than one-third (or $33.3 \%$ ) of total area. Parit was the most prominent with the shophouse having $73.5 \%$ of the total area for the domestic space; Bagan Datuk, 68.4\%, Tanjung Rambutan, 62.2\%, Manong, 61.3\%, and Klian Intan, $60.5 \%$. Whereas, for the shophouses at the other ten towns which were Pengkalan Hulu, Lenggong, Chenderiang, Padang Rengas, Papan, Malim Nawar, Kuala Kurau, Pusing, Lumut and Sungkai, the allocation was between $40 \%$ to $59 \%$ space area. At Kuala Sepetang, the unit had the smallest area at $39.4 \%$ for the domestic space.

Not all of the 16 towns in this study allocated an open space in their layout, among them Klian Intan, Manong and Parit. Of the other 13 towns, this said space was less than one-third (33.3\%) of the total area. Only in Kuala Sepetang and Chenderiang was this area reflected as $27.9 \%$ in the respective shophouses.

Therefore, if main space is defined as having the biggest area, the domestic space is considered the most important in all the shophouses as it allocates more than one-third of $33.3 \%$ of the total area when compared to the other spaces within the shophouse.

\section{Conclusion}

Overall, from the remeasurement of the 16 shophouses in the 16 small towns in Perak, it emphasise that the way of life was the main factor in the layout of these early buildings. The most important focus was allocated to space for domestic use, such as to come together, bedroom, kitchen and dining. Although the shophouse moniker reflected a dual-function term, 'shop' and 'house', its construction was predominantly purposed for residence followed by commercial activity. Nevertheless, the business space claims priority by being at the very front to facilitate customers and trade. Situated there, it also separates the public space from the private space in the shophouse. Though smaller than the domestic area, the business space was vital in its position as it was the link to the five-footway in front of the unit.

Apart from this, the study also reveals the layout and space usage with raw and first-hand data for various other studies in future. It may spearhead explorations into the influence of economic activity to the building of shophouses in terms of size and layout, including types of space, design of openings determined by lighting and natural ventilation in a building, activity and lifestyle relationship in the use of space, adaptability of space for new activity, and numerous other studies. Therefore, the considerable importance attributed to layout and space function in a shophouse opens the door to other aspects in fields of knowledge, social culture, and socio-economy.

\section{Acknowledgements}

This research is a large-scale study which was characterised as an inventory and data recording exercise initially for the requirement of government administration and policy planning. However, the information that was derived from it is vital knowledge in multiple aspects. The data contained in it have been analysed and manifested in a written article which can be adopted in different fields of study, especially that of architecture, town planning and interior space design. As such, this article owes its gratitude to the Perak Town and Country Planning Department and Universiti Sains Malaysia, which had provided a research grant for it. Appreciation for its culminated success also goes to, Ungku Omar Polytechnic, Perak Heritage Society, as well as other individuals who have contributed their efforts directly or indirectly in the relevant towns under study.

\section{References}

1. Anjali Krishan Sharma (2017), Historic city - A case of resilient built environment, Procedia Engineering, 180, 1103 - 1109.

2. Chen Shih-Ming, Song Hung-Chi (2011), A Study on the Minimal Preservation for the Historical ShopHouse Renewal, Applied Mechanics and Materials, Vols. 71-78, pp 4899-4902.

3. Chee Siang Tan \& Kaori Fujita (2014), Building Construction of Pre-war Shophouses in George Town Observed Through a Renovation Case Study, Journal of Asian Architecture and Building Engineering, $13: 1,195-202$ 
4. Christopher T. Sneed, Rodney Runyan, Jane L. Swinney \& Hee-Jin Lim (2011), Brand, business mix, sense-of-place: do they matter downtown?, Journal of Place Management and Development, Vol. 4, No. 2, pp. 121-134.

5. Cleber da Costa Webber, Jorge Oneide Sausen, Kenny Basso and Claudionor Guedes Laimer (2018), Remodelling the retail store for better sales performance, International Journal of Retail \& Distribution Management, Vol. 46 No. 11/12, pp. 1041-1055.

6. Gunes Acelya Sipahia, Ogr. Gor. Didem Enginoglu (2015), Retail Planning Studies: an Application Oriented at Consumers' Perception of The Quality of Retail Environment, Procedia - Social and Behavioral Sciences, 177, 481 - 490.

7. Ho Tak Ming (2009), When Tin Was King, Perak Academy, Ipoh, Perak, ISBN 978-983-42500-2-7

8. Jae-Eun Kim, Jieun Kim, (2012), Human factors in retail environments: a review, International Journal of Retail \& Distribution Management, Vol. 40 Issue: 11, pp.818-841

9. Khare Arpita, (2014), Consumer-small retailer relationships in Indian retail, Facilities, Vol. 32 Issue: 9/10, pp.533-553.

10. Khoo Salma Nasution \& Abdur Razzaq Lubis (2005), Kinta Valey, Pioneering Malaysia's Modern Developtment, Perak Academy, Ipoh, Perak, ISBN 983-42113-0-9.

11. Kwok Wah Tung (2018) Chikan's Arcade Buildings: The Hybrid and Civil Architecture of Lingnan, Architecture and Culture, 6:2, 329-351.

12. Laina Hilma Sari (2018), A review of spatial comfort in shophouse in humid tropics, IOP Conf. Ser.: Mater. Sci. Eng. 352.

13. Lesley Hoskins \& Rebecca Preston (2018), Behind the Scenes: Participants and Processes in the Development of London's Interwar Suburban Shopping Parades, Architecture and Culture, 6:1, 99-121.

14. Mohd Azuan Zakaria, Tetsu Kubota, Doris Hooi Chyee Toe (2015), The Effects of Courtyards on Indoor Thermal Conditions of Chinese Shophouse in Malacca, Procedia Engineering, 121, 468 - 476.

15. Mohd Jaki Mamat \& Muhammad Firzan Abdul Aziz (2018), Early Town Planning System of Small Towns in Perak, Planning Malaysia: Journal of the Malaysian Institute of Planners, Volume 16, Issue 4, Page $55-67$

16. Mohd Jaki Mamat \& Muhammad Firzan Abdul Aziz (2020), The Entity - Identity Relationships of Old Shop Houses In Perak Through Facade Design, Planning Malaysia: Journal of the Malaysian Institute of Planners, Volume 18, Issue 3, Page $51-70$.

17. N.A.M. Omar, S.F.Syed-Fadzil (2011), Assessment of Passive Thermal Performance for a Penang Heritage Shop house, Procedia Engineering, 20, 203 - 212.

18. Paul Jones (2019), The Shaping of Form and Structure in Informal Settlements: A Case Study of Order and Rules in Lebak Siliwangi, Bandung, Indonesia, Journal of Regional and City Planning, vol. 30, no. 1, page. 43-61.

19. Raed M. A. Elottol \& Azizi Bahauddin (2011), The relationship between interior space design and visitors' satisfaction: a case study of Malaysian museums (interior circulation scheme), The International Journal of Organizational Innovation - Volume 3, Number 4, page 158-179.

20. Rina Kurniati, Febri Ratno Erlambang (2015), Changes the pattern of residential space into commercial space in chinatown semarang, Procedia Environmental Sciences, 23, 307 - 314.

21. Shahrul Yani Saida, Zalina Samadi (2016), The Evolution of Historic Streetscape in Adapting Modern Demand in Achieving the Quality of Life, Procedia - Social and Behavioral Sciences, 234, 488 - 497

22. Shi Yin, Yiqiang Xiao (2016), Scale Study of Traditional Shophouse Street in South of China Based on Outdoor Thermal Comfort, Procedia Engineering, 169, 232 - 239.

23. Song Hung-Chi, Huang Long-Sheng (2014), A Preservation Research for the Historical Shop-House Renewal through Volume Control - Two Case Studies in Qishan Dist., Kaohsiung City, Applied Mechanics and Materials, Vols. 584-586, pp 168-172.

24. Song Hung-Chi, Chen Shih-Ming (2011), An Investigation on the Transformations of the Traditional House in the Modern Lifestyle - A Case Study in the Shop-Houses in Tainan City, Applied Mechanics and Materials, Vols. 71-78, pp 4894-4898.

25. Tetsu Kubota, Mohd Azuan Zakaria, Seiji Abe, Doris Hooi Chyee Toe (2017), Thermal functions of internal courtyards in traditional Chinese shophouses in the hot-humid climate of Malaysia, Building and Environment, 112, 115-131.

26. Tony Kent (2007), Creative space: design and the retail environment, International Journal of Retail \& Distribution Management, Vol. 35 Issue: 9, pp.734-745,

27. Wadu Mesthrige Jayantha and Esther Hiu Kwan Yung (2018), Effect of Revitalisation of Historic Buildings on Retail Shop Values in Urban Renewal: An Empirical Analysis, Sustainability, 10, 1418.

28. Wahyuni Zahrah and Achmad Delianur Nasution ( 2015 ), Urban design guideline for shophouses: a temperature modification approach, Procedia - Social and Behavioral Sciences, 179, 308 - 317. 
29. Wan Hashimah Wan Ismail (2015), Contemporary Uses of Buildings on a Heritage Street, Procedia Social and Behavioral Sciences, 170, 633 - 641.

30. Wang Han, Jia Beisi (2015), A morphology study of traditional shophouses in China and Southeast Asia, Procedia - Social and Behavioral Sciences, 179 ( 2015 ) 237 - 249.

31. Wei Zhang, Kumar Rajaram (2017), Managing limited retail space for basic products: Space sharing vs. space dedication, European Journal of Operational Research, 263, 768-781.

32. William Wee Lim Hew, David Yoon Kin Tong, Gerald Guan Gan Goh, (2014), Revitalisation of the Old Township of Ipoh, Malaysia, Journal of Place Management and Development, Vol. 7 Issue: 1, pp.57-73.

33. Yung Ren Tan (2019), Reconstituted Village: Relocating Traditional Houses and Transforming Traditional Malay Villages, Journal of Regional and City Planning, vol. 30, no. 3, page. 261-272. 